\title{
A study of some major testicular steroids in the pig in relation to their effect on the development of male characteristics in the prepubertally castrated boar
}

\author{
W. D. Booth \\ A.R.C. Institute of Animal Physiology, Animal Research Station, 307 Huntingdon Road, \\ Cambridge CB3 OJQ, U.K.
}

\begin{abstract}
Summary. Prepubertally castrated boars received subcutaneous injections twice weekly, from 12 to 38 weeks of age, of testosterone or 5-androstenediol (5-androstene- $3 \beta, 17 \beta$-diol) $(2 \mathrm{mg} / 5 \mathrm{~kg})$, or each of these steroids in combination with oestrone $(1 \mathrm{mg} / 5 \mathrm{~kg})$. All steroid treatments induced growth and secretory activity of the accessory organs. The prostate was maintained best by testosterone, and the seminal vesicles by 5 -androstenediol. No specific effects of oestrone on these organs were found. Champing of excess saliva was induced in all treated pigs when they were introduced to an oestrous gilt, but only boars receiving testosterone displayed intense mating behaviour including mounting and, in 3 animals, ejaculation; no specific effects of oestrone on behaviour were seen. Low normal levels of unconjugated androgen, and normal to high levels of unconjugated oestrogen were circulating in the treated pigs. There was evidence that peripheral metabolism of exogenous steroids had occurred: 5-androstenediol to testosterone, these two androgens to oestrogen, and sulphation of oestrogen. The sulphate conjugates of dehydroepiandrosterone, 5-androstenediol and oestrone predominated in the peripheral plasma of mature intact boars. Concentrations of $3 \alpha$-androstenol ( $5 \alpha$-androst-16-en-3a-ol) in the submaxillary glands of androgen-treated pigs were similar to those in untreated castrates, thus indicating that androgens are probably not precursors of the pheromonal 16-androstene steroids in vivo.
\end{abstract}

\section{Introduction}

The testis of the male pig produces, in addition to testosterone, large quantities of other $\mathrm{C}_{19}$ steroids (Baulieu, Fabre-Jung \& Huis in't Veld, 1967; Raeside \& Howells, 1971; Ruokonen \& Vihko, 1974; Segal \& Raeside, 1975; Booth, 1975). Some of these $C_{19}$ steroids, notably dehydroepiandrosterone (DHA) and 5-androstenediol may be important precursors of testosterone in the pig testis, as they are in the testis of dogs (Yamaji, Motohashi, Tanioka \& Ibayashi, 1968; Oh \& Tamaoki, 1973) and man (Vihko \& Ruokonen, 1975). These 5-unsaturated $\mathrm{C}_{19}$ steroids may also be prohormones for testosterone in androgen end-target organs, and Booth (1977) has shown that DHA and especially 5-androstenediol are readily converted to testosterone and $5 \alpha$-reduced metabolites in the submaxillary salivary gland of the boar. This finding and other evidence (Booth, 1972, 1975; Booth, Hay \& Dott, 1973) indicates that the submaxillary gland is an important androgen end-target organ in the male pig, modified to accumulate and release the pheromonal 16 -unsaturated $C_{19}$ steroids (16-androstenes). These musk-swelling steroids are synthesized by a route independent of androgen 
production (Gower, 1972) in boar testis where they occur in concentrations considerably higher than those of testosterone (Ruokonen \& Vihko, 1974; Booth, 1975). It has been suggested that, in vivo, androgens may be precursors for 16 -androstene steroids in extragonadal tissues, but evidence to support or refute this suggestion is lacking.

The boar and the stallion are unusual among male animals in that their testes produce large quantities of oestrogen (Raeside, 1965, 1969; Velle, 1966); little is known about the physiological significance of this oestrogen, but Joshi \& Raeside (1973) have shown that oestrogen acts synergistically with testosterone to enhance both the secretory activity of accessory organs and sexual behaviour in boars castrated after puberty.

The aims of the present work to elucidate further some physiological effects of testicular steroids in the boar were: (1) to find out if 5-androstenediol has significant androgenic activity compared with testosterone; (2) to study the possibility that oestrogen may act synergistically with androgen to induce the development of certain male characteristics; (3) to carry out a detailed analysis of androgens and oestrogen in the peripheral blood of intact boars so that effects arising from treating castrated boars with steroids could be evaluated in relation to the intact animal; and (4) to resolve the question of whether androgens are converted to 16 -androstene steroids.

\section{Materials and Methods}

\section{Animals and treatments}

The pigs were Large White, or predominantly Large White cross Essex. At 10 weeks of age, 15 pigs were castrated and the litters mixed. Those pigs destined to receive steroid injections (Groups A, B, C, D) were housed in two covered pens, each containing 6 pigs randomized with respect to body weight. The other 3 castrates were controls (Group E), housed in a third identical pen. All pigs were weighed at weekly intervals until they were slaughtered at 38 weeks of age. Ten additional castrated boars (Group F, 38 weeks old), and 12 intact boars (Group G, 4 pigs; Group H, 8 pigs, 47-49 weeks old) were slaughtered to provide control data.

Steroids were purchased from Sigma (Poole, Dorset, U.K.). The following steroids suspensions in arachis oil were prepared: testosterone $(20 \mathrm{mg} / \mathrm{ml}), 5$-androstenediol $(20 \mathrm{mg} / \mathrm{ml})$, and the same two steroid suspensions each including oestrone $(10 \mathrm{mg} / \mathrm{ml})$. At 4 weeks after castration, the pigs in Groups A-D were given twice weekly subcutaneous injections of steroid. Pigs in Groups A and B in one of the pens received testosterone and 5-androstenediol, respectively, while pigs in Groups $\mathrm{C}$ and $\mathrm{D}$ received testosterone + oestrone, and 5 -androstenediol + oestrone respectively. The amounts injected were $2 \mathrm{mg}$ testosterone or 5 -androstenediol $/ 5 \mathrm{~kg}$ and $1 \mathrm{mg}$ oestrone $/ 5 \mathrm{~kg}$. The Group E pigs received no injections.

During the last month of steroid treatment, 3 blood samples were collected at weekly intervals, 2 days after a steroid injection, into heparinized syringes from the anterior vena cava of each pig in Groups A-D. Blood samples were also collected from castrated boars in Group F, and intact boars in Group $\mathrm{H}$ at the slaughterhouse. The blood was centrifuged and the plasma samples stored frozen $\left(-20^{\circ} \mathrm{C}\right)$ until required for steroid analysis.

\section{Steroid determinations}

The radioimmmunoassays of unconjugated androgen (Booth \& Baldwin, 1980) and total unconjugated oestrogen (Newcomb, Booth \& Rowson, 1977) were as previously described. Total oestrogen sulphate was determined by a method similar to that described by Loriaux, Ruder \& Lipsett (1971), and applied to pig plasma by Robertson \& King (1974). Samples $(0.043-3.44 \mathrm{ng})$ of oestrone sulphate, triethylammonium salt (a gift from the M.R.C. Steroid Reference Collection, Westfield College, London, U.K.) were taken for the standard curve. Due 
to non-specific binding factors in plasma, charcoal-stripped plasma from an ovariectomized pig was used as blank medium for the standard curve samples in the oestrogen sulphate assay. The tracer steroid for the radioimmunoassay was $\left[2,4,6,7(n)-{ }^{3} \mathrm{H}\right]$ oestradiol-17 $\beta$ (sp. act. $4 \cdot 0$ $\mathrm{TBq} / \mathrm{mmol}$ : Radiochemical Centre, Amersham, Bucks, U.K.). Cross-reactions to the antiserum used have been given previously (Newcomb et al., 1977), but the relatively high cross-reaction for oestrone $(55 \%)$ enabled the antiserum to be used for the determination of oestrogen in boar plasma since oestrone is known to be the predominant oestrogen in the boar. Oestrone was used for the standard curve in the radioimmunoassay of total unconjugated oestrogen in plasma. Both oestrone and oestradiol-17 $\beta$ were used for standard curves when plasma extracts of mature boars (Group $\mathrm{H}$ ) were fractionated into oestrone and oestradiol-17 $\beta$ by thin-layer chromatography as described by Singh \& Booth (1978). The minimum amount of oestrogen measurable in the sulphate fraction was $20-50 \mathrm{pg}$, and the interassay coefficient of variation was $8 \cdot 1 \%(n=$ 5). Recovery estimations using $\left[6,7(n)-{ }^{3} \mathrm{H}\right]$ oestrone sulphate ammonium salt (New England Nuclear, Dreieich, W. Germany) were in the range $67 \cdot 3-73 \cdot 7 \%(n=6)$.

Samples of blood plasma $(100 \mathrm{ml}$ ) from 2 mature boars (Group $\mathrm{H}$ ) were subjected to a detailed extraction, purification and identification procedure, with the aim of determining the relative concentrations of some individual androgens and oestrogens in boar plasma so that the specificity of the radioimmunoassays of total androgen and oestrogen could be more clearly defined. Trace amounts of ${ }^{3} \mathrm{H}$-labelled steroids for recovery purposes (Booth, 1975) were added to the plasma before extraction with diethyl ether $(500 \mathrm{ml})$ to remove unconjugated steroids. Gross lipid was removed from the ether extract by partitioning it between $20 \mathrm{ml}$ light petroleum ether (b.p. $40-60^{\circ} \mathrm{C}$ ) and $70 \%$ aqueous methanol $(6 \times 70 \mathrm{ml})$. The methanolic extract was subsequently subjected to the Brown's partition (Brown, 1955) to provide separate neutral and phenolic fractions. Androgens were isolated by a combination of thin-layer and paper chromatography (Booth, 1977) and the steroids were quantified by gas-liquid chromatography Booth (1975). Oestrone and oestradiol-17 $\beta$ were separated from each other by thin-layer chromatography and quantified either by radioimmunoassay (Singh \& Booth, 1978), for unconjugated oestrogens, or by gas-liquid chromatography (conjugated oestrogens) as described above. After ether extraction of the plasma, the latter was saturated with $\mathrm{NaCl}(25 \mathrm{~g})$ and the steroid sulphates were extracted with ethyl acetate :ethanol $(3: 1 \mathrm{v} / \mathrm{v})$. The solvent phase was filtered through Whatman No. 1 filter paper before removal by rotary vacuum evaporation. One-fifth of the extract was hydrolysed according to Burstein \& Lieberman (1958) to give free androgens, the remainder of the extract was hydrolysed with glacial acetic acid (Robertson \& King, 1974) to give free oestrogens. The resulting free steroids were then isolated as described above for the unconjugated steroids.

The amounts of $3 \alpha$-androstenol ( $5 \alpha$-androst-16-en-3 3 -ol) in submaxillary salivary glands were determined by methods described previously (Booth, 1972, 1975). The tissue from the pigs in each of Groups A-E was pooled and extracted.

\section{Development of androgen-dependent glands}

After slaughter the genital tract and submaxillary salivary glands were removed, and the prostate, seminal vesicles, bulbourethral glands and submaxillary glands were weighed; pieces of tissue from these glands were fixed in Bouin's fluid for histology. The seminal vesicles were stored frozen at $-80^{\circ} \mathrm{C}$ pending the analysis of fructose as described by Lindner \& Mann (1960), and zinc according to Booth \& Baldwin (1980).

\section{Mating behaviour}

This aspect was not investigated in detail, as only one test was carried out on the day before the steroid-treated pigs were slaughtered. The treated pigs were introduced individually to a 
neutral pen housing a gilt (2nd day of oestrus), and the behaviour of the pig was observed for 10 min before removal of the male.

\section{Statistical analysis}

An analysis of variance was carried out by the A.R.C. Statistics Group, Cambridge, on data relating to body weights and androgen responsive glands after transformation of the data to a logarithmic scale.

\section{Results}

\section{Body weight and androgen-dependent glands}

Live body weights on the day of slaughter were around $100 \mathrm{~kg}$ (see Table 1); there was no significant difference $(P>0.05)$ in body weights of pigs receiving the different steroid treatments and untreated pigs. During the early weeks of steroid treatment, enlargement of the teats occurred in those pigs receiving oestrone, but these regressed later in the treatment period.

Table 1. Mean \pm s.e.m. body weights and organ weights (single glands) in boars castrated prepubertally and receiving steroid injections (Groups A-D, see 'Methods') and in untreated castrated (Group E) and intact (Group G) boars

\begin{tabular}{|c|c|c|c|c|c|c|}
\hline \multirow[b]{2}{*}{ Group } & \multirow[b]{2}{*}{ No. of pigs } & \multirow[b]{2}{*}{$\begin{array}{l}\text { Body wt } \\
(\mathrm{kg})\end{array}$} & \multicolumn{4}{|c|}{ Gland weights (g) } \\
\hline & & & Prostate & $\begin{array}{l}\text { Seminal } \\
\text { vesicle }\end{array}$ & $\begin{array}{l}\text { Bulbo- } \\
\text { urethral }\end{array}$ & $\begin{array}{l}\text { Submaxillary } \\
\text { salivary }\end{array}$ \\
\hline A & 3 & $93.6 \pm 6.65$ & $9.20 \pm 2.62^{*}$ & $38 \cdot 0 \pm 5 \cdot 59$ & $70.9 \pm 10.9$ & $18.4 \pm 0.20$ \\
\hline B & 3 & $102 \pm 9.83$ & $5.40 \pm 0.57$ & $32.8 \pm 3.43$ & $49.0 \pm 4.86$ & $20.3 \pm 0.92$ \\
\hline $\mathrm{C}$ & 3 & $103 \pm 7.57$ & $7 \cdot 17 \pm 1 \cdot 37$ & $28 \cdot 9 \pm 3 \cdot 31$ & $56.9 \pm 5.63$ & $21.2 \pm 0.54$ \\
\hline D & 3 & $112 \pm 8.03$ & $4 \cdot 20 \pm 1 \cdot 50^{*}$ & $64.2 \pm 8.86 \dagger$ & $40.7 \pm 7.10$ & $22.1 \pm 1.01$ \\
\hline $\mathrm{E}$ & 3 & $86.0 \pm 8.09$ & $0.56 \pm 0.03$ & $0.94 \pm 0.11$ & $5.29 \pm 0.14$ & $20.3 \pm 1.58$ \\
\hline G & 4 & - & $11.8 \pm 1.27$ & $211 \pm 5 \cdot 51$ & $122 \pm 2 \cdot 60$ & $54.9 \pm 0.56$ \\
\hline
\end{tabular}

* Significantly different from values in Groups $\mathrm{A}-\mathrm{C}, P<0.05$ (ANOVA).

$\dagger$ Significantly different from values in Groups A-C, $P<0.05$ (ANOVA).

All steroid treatments resulted in an increase in the weights of the accessory glands (Table 1). Light microscopy of sections of the prostate and seminal vesicle glands showed that their increased weight in the steroid-treated pigs was due to a marked development of secretory epithelium similar to that seen in the glands of mature intact boars, and the alveoli of the prostates and seminal vesicles also contained appreciable amounts of secretion. Apart from the prostate gland, which had been well supported by testosterone alone or in combination with oestrone, none of the other accessory organs in the steroid treated pigs was as large as those in intact boars (Group G). The largest seminal vesicles were present in Group D pigs only. Zinc levels in the seminal vesicles were also significantly higher in the pigs in Group D, but very much higher values were found in the seminal vesicles of intact boars (Group G). Neither the accessory organs nor the submaxillary glands showed any effects which could be related to the oestrogen treatment (Table 2).

Submaxillary gland weights were unaffected by the treatments in Groups A-E (Table 1), but Group $\mathrm{G}$ values were more than twice as great. 
Table 2. The mean \pm s.e.m. content of fructose and zinc in the paired seminal vesicles in boars castrated prepubertally and receiving steroids (Groups A-D, see 'Methods') and in untreated castrated (Group E) and intact (Group G) boars

\begin{tabular}{|c|c|c|c|c|}
\hline \multirow[b]{2}{*}{ Group } & \multirow[b]{2}{*}{ No. of pigs } & \multicolumn{3}{|c|}{ Seminal vesicles } \\
\hline & & $\begin{array}{c}\text { Weight } \\
\text { (g) }\end{array}$ & $\begin{array}{c}\text { Fructose } \\
\text { (mg) }\end{array}$ & $\begin{array}{l}\text { Zinc } \\
\text { (mg) }\end{array}$ \\
\hline $\mathbf{A}$ & 3 & $76.0 \pm 9.60$ & $62 \cdot 5 \pm 24 \cdot 3$ & $5.55 \pm 1.32$ \\
\hline B & 3 & $65.7 \pm 8.85$ & $34 \cdot 1 \pm 12 \cdot 7$ & $6.13 \pm 1.20$ \\
\hline $\mathrm{C}$ & 3 & $57.8 \pm 8.78$ & $46.7 \pm 31 \cdot 2$ & $2.69 \pm 0.57$ \\
\hline D & 3 & $128 \pm 24 \cdot 6^{*}$ & $104 \pm 40.7$ & $17.7 \pm 1.54$ \\
\hline $\mathrm{E}$ & 3 & $1.88 \pm 0.24$ & $0.053 \pm 0.017$ & $0.035 \pm 0.005$ \\
\hline G & 4 & $421 \pm 5 \cdot 30$ & $69.4 \pm 23.0$ & $60.5 \pm 11.3$ \\
\hline
\end{tabular}

* Significantly different from values in Groups A-C, $P<0.05$ (ANOVA).

$\uparrow$ Significantly different from values in Groups A-C, $P<0.05$ (ANOVA).

\section{Steroids in peripheral plasma}

Unconjugated androgen concentrations were considerably higher in all steroid-treated pigs than in untreated castrated boars, but not as high as in the intact animals (Table 3). However, in pigs receiving oestrone plasma values of unconjugated oestrogen were more than 20 -fold higher than in untreated castrates, and were also at least 2-fold higher than in the intact boars (Group $\mathrm{H})$. Conjugated oestrogen concentrations were similarly higher in the plasma of the oestrone-treated pigs than in the control castrates, but were considerably lower than values in intact boars. Both unconjugated and conjugated oestrogen levels were higher in the plasma of pigs in Groups $\mathbf{C}$ and $\mathrm{D}$ compared with those in Groups $\mathrm{E}$ and $\mathbf{F}$; in all pigs conjugated oestrogen concentrations were higher than unconjugated oestrogen values.

Table 3. The mean \pm s.e.m. concentrations of androgen and oestrogen in the peripheral plasma of boars castrated prepubertally and receiving steroids (Groups A-D, see 'Methods') and in untreated castrated (Groups E + F) and intact (Group $\mathrm{H}$ ) boars

\begin{tabular}{|c|c|c|c|}
\hline Group & $\begin{array}{c}\text { Unconjugated } \\
\text { androgen (ng/ml) }\end{array}$ & $\begin{array}{c}\text { Unconjugated } \\
\text { oestrogen }(\mathrm{pg} / \mathrm{ml})\end{array}$ & $\begin{array}{l}\text { Sulphate-conjugated } \\
\text { oestrogen }(\mathrm{ng} / \mathrm{ml})\end{array}$ \\
\hline$A^{*}$ & $\begin{array}{l}3.72 \pm 1.16 \\
3.47 \pm 0.02 \\
4.10 \pm 2.31\end{array}$ & $\begin{array}{l}491 \pm 124 \\
718 \pm 36 \cdot 8 \\
730 \pm 266\end{array}$ & $\begin{array}{l}1.99 \pm 0.93 \\
1.81 \pm 0.37 \\
2.14 \pm 0.40\end{array}$ \\
\hline $\mathrm{B}^{*}$ & $\begin{array}{l}3.08 \pm 0.48 \\
2.20 \pm 0.46 \\
2.62 \pm 0.90\end{array}$ & $\begin{array}{l}853 \pm 89.9 \\
683 \pm 381 \\
953 \pm 102\end{array}$ & $\begin{array}{l}2.24 \pm 0.85 \\
0.83 \pm 0.16 \\
1.56 \pm 0.52\end{array}$ \\
\hline$C^{*}$ & $\begin{array}{l}4.12 \pm 1.20 \\
2.62 \pm 0.46 \\
2.80 \pm 0.72\end{array}$ & $\begin{array}{r}86.6 \pm 7.99 \\
59.1 \pm 10.8 \\
104 \pm 21.5\end{array}$ & $\begin{array}{l}0.20 \pm 0.12 \\
0.09 \pm 0.05 \\
0.28 \pm 0.15\end{array}$ \\
\hline$D^{*}$ & $\begin{array}{l}1.30 \pm 0.30 \\
1.48 \pm 0.19 \\
2.23 \pm 0.45\end{array}$ & $\begin{array}{r}108 \pm 34.6 \\
87.2 \pm 10.4 \\
65.4 \pm 6.03\end{array}$ & $\begin{array}{l}0.15 \pm 0.01 \\
0.43 \pm 0.18 \\
0.63 \pm 0.15\end{array}$ \\
\hline $\mathrm{E}+\mathrm{F}^{\dagger} \quad$ (13) & $0.22 \pm 0.06$ & $38.5 \pm 6.45$ & $0.09 \pm 0.01$ \\
\hline $\mathrm{H}^{\dagger} \quad(8)$ & $8 \cdot 13 \pm 2.04$ & $352 \pm 50.9$ & $83 \cdot 7 \pm 19 \cdot 4$ \\
\hline
\end{tabular}

* Values are for 3 plasma samples collected at weekly intervals from each pig during the last 20 days of treatment.

$\dagger$ Values are means \pm s.e.m. from single plasma samples for each pig (no. in parentheses). 
Detailed analyses of steroids in the peripheral plasma of 2 mature intact boars (Boars 6 and Fred) provided the following data. Testostosterone, 17.6 and $13.9 \mathrm{ng} / \mathrm{ml}$; androstenedione, $7.8 \mathrm{ng} / \mathrm{ml}$ and not measurable; $5 \alpha$-dihydrotestosterone, 0.6 and $1.2 \mathrm{ng} / \mathrm{ml}$; DHA, 2.4 and 0.9 $\mathrm{ng} / \mathrm{ml}$; DHA sulphate, 115 and $175 \mathrm{ng} / \mathrm{ml} ; 5$-androstenediol, 1.6 and $1.5 \mathrm{ng} / \mathrm{ml} ; 5$ androstenediol sulphate, 243 and $389 \mathrm{ng} / \mathrm{ml}$; oestrone, 50 and $79.5 \mathrm{pg} / \mathrm{ml}$; oestrone sulphate, 8.1 and $32.0 \mathrm{ng} / \mathrm{ml}$; oestradiol $-17 \beta, 30.0$ and $26.0 \mathrm{pg} / \mathrm{ml}$; oestradiol-17 $\beta$ sulphate, not measurable and $8 \cdot 5 \mathrm{ng} / \mathrm{ml}$.

\section{3a-Androstenol in submaxillary glands}

Low levels of this pheromonal steroid were found in all submaxillary gland extracts of both treated and untreated (Group E) castrated pigs. The amounts of $3 \alpha$-androstenol $(\mu \mathrm{g} / 100 \mathrm{~g})$ were $24 \cdot 1,30 \cdot 4,12 \cdot 5$, trace and $20 \cdot 8$ for pigs in Groups A, B, C, D and E, respectively.

\section{Mating behaviour}

All castrated boars receiving steroids vigorously champed excessive amounts of saliva in the presence of the oestrous pig. Mounting behaviour by the pigs receiving testosterone (Groups A and C) was more vigorous and 3 of these animals ejaculated. There was no distinctive behaviour exhibited which could be related to the oestrogen treatment.

\section{Discussion}

Since there were only 3 animals in each experimental group, detailed comparisons of effects due to different steroid treatments must be cautious.

Testosterone was better than 5-androstenediol in supporting the growth and secretory activity of the prostate in the castrated boars, and this is in keeping with the known requirement for testosterone and its $5 \alpha$-reduced metabolites (Booth \& Jones, 1979) by the prostates of other species.

The much higher levels of fructose and zinc found in the seminal vesicles of the steroid-treated pigs, when compared with the low levels found in the glands of untreated castrated controls, is a reflection of androgen action on the glands (Lindner \& Mann, 1960; Müntzing, Kirdani, Murphy \& Sandberg, 1977). Comparing the levels of fructose and zinc found in the seminal vesicles of the steroid-treated pigs with those in the glands of intact boars indicates that zinc content is more closely related to the degree of androgen stimulation of the accessory organ than is fructose.

5-Androstenediol has moderate androgenic activity in the chick's comb assay (Dorfman \& Dorfman, 1963), and, as shown in the present study, appears to be a relatively potent androgen in the boar. This finding indicates that the high levels of unconjugated and sulphate-conjugated 5-androstenediol produced by the boar testis (Raeside \& Howells, 1971; Ruokonen \& Vihko, 1974; Segal \& Raeside, 1975; Booth, 1975) may add significantly to the total pool of active androgen in the boar. The androgenic effect of 5-androstenediol could be due to a direct effect of the steroid on the gland, or related to its conversion to potent androgens such as testosterone and $5 \alpha$-dihydrotestosterone, either within the gland, as demonstrated for the submaxillary gland of the boar (Booth, 1977), or in other peripheral sites. In support of the latter suggestion was the finding of raised levels of plasma androgen in those pigs receiving 5-androstenediol; as this steroid has a relatively low cross-reaction (9\%) with the antibody used in the radioimmunoassay, it is likely that it was testosterone formed peripherally from 5 -androstenediol that 
was the major androgen being measured. Unfortunately this could not be confirmed by gas-liquid chromatography of individual androgens because there was insufficient plasma.

In the intact boar, the testis contains large quantities of both unconjugated and conjugated 5-androstenediol (Booth, 1975) while the peripheral blood plasma contains relatively low levels of unconjugated 5-androstenediol and high levels of sulphate-conjugated 5-androstenediol (Raeside \& Howells, 1971; present study). The very high levels of sulphate-conjugated 5-unsaturated $\mathrm{C}_{19}$ steroids in boar plasma suggests a pool of active androgen (Notation, 1975), or a pool of irreversibly inactivated androgen.

The lack of effect of injected oestrogen in combination with androgen is contrary to the findings of Joshi \& Raeside (1973) who used a similar ratio of testosterone to oestrogen but found an enhancement of the secretory activity of accessory organs and of sexual behaviour in boars. However, Joshi \& Raeside (1973) were giving steroid replacement to boars which had been castrated when they were fully mature, and other experimental conditions were not comparable with those in the present study.

The levels of sulphate-conjugated oestrogen in the oestrogen-treated pigs, although higher than those of unconjugated oestrogen, were much lower than the levels in intact boars. These findings indicate that the testis is indeed a major source of oestrogen sulphate in the boar, as demonstrated by other studies (Raeside, 1965; Velle, 1966). However, the finding of higher concentrations of both unconjugated and conjugated oestrogen in the plasma of castrated boars treated with androgens alone than in untreated castrates indicates that the aromatization of androgens to oestrogens, and some sulphation of these oestrogens, can occur peripherally in the boar. Significant extragonadal, extrahepatic aromatization of androgens is known to occur postnatally in man, but excess activity is rare (Hemsell, Edman, Marks, Siiteri \& MacDonald, 1977). The question still remains as to whether oestrogen sulphates have an oestrogenic function in the boar.

Testosterone was better than 5-androstenediol in supporting mating behaviour of the castrated boar, a finding in keeping with studies in the rat (Morali, Larsson, Perez-Palacios \& Beyer, 1975). This is probably related to the fact that testosterone is a direct substrate for aromatization to oestrogen in neural tissue (Callard, Petro \& Ryan, 1978), a necessary prerequisite for the expression of reproductive behaviour in males and females (Naftolin et al., 1975), whereas 5-androstenediol would need to be converted to a 4-unsaturated $C_{19}$ steroid such as testosterone before aromatization. The champing of excess saliva in the steroid-treated pigs seems to be an androgen-dependent phenomenon because it has been observed in ovariectomized pigs receiving testosterone when introduced to strange pigs (W. D. Booth, unpublished). There seem to be two effects of androgen on salivation in the pig, one facilitating the neural mechanisms controlling salivation, and the other leading to hypertrophy of the gland, since the steroid-treated pigs salivated profusely in the absence of submaxillary gland enlargement. This lack of submaxillary gland enlargement indicates that this gland has a higher threshold response to androgen than do the accessory organs.

The saliva of castrated or ovariectomized pigs receiving androgen injections was essentially devoid of the pheromonal 16-androstene steroids; warming of the saliva on a watchglass did not produce the distinctive odour of the 16-androstene steroid and very low concentrations of $3 \alpha$-androstenol were found in submaxillary gland extracts, a finding similar to that in untreated castrates or female pigs. This indicates that androgens are not likely to be significant precursors for 16-androstene synthesis in vivo, a conclusion in agreement with the in-vitro studies of Gower (1972). However, there is still the possibility that other androgen-dependent pheromones could be produced in castrated or ovariectomized pigs receiving androgen and thus cause these pigs to be attractive to oestrous females (Signoret, 1974).

I thank Mrs J. S. Reed and Mr K. I. von Glos for able technical assistance. 


\section{References}

Baulieu, E.E., Fabre-Jung, I. \& Huis in't Veld, L.G. (1967) Dehydroepiandrosterone sulfate: a secretory product of the boar testis. Endocrinology 81, 34-38.

Booth, W.D. (1972) The occurrence of testosterone and $5 \alpha$-dihydrotestosterone in the submaxillary gland of the boar. J. Endocr. 55, 119-125.

Booth, W.D. (1975) Changes with age in the occurrence of $\mathrm{C}_{19}$ steroids in the testis and submaxillary gland of the boar. J. Reprod. Fert. 42, 459-472.

Booth, W.D. (1977) Metabolism of androgens in vitro by the submaxillary salivary gland of the mature domestic boar. J. Endocr. 75, 145-154.

Booth, W.D. \& Baldwin, B.A. (1980) Lack of effect on sexual behaviour or the development of testicular function after removal of olfactory bulbs in prepubertal boars. J. Reprod. Fert. 58, 173-182.

Booth, W.D. \& Jones, R. (1979) Metabolism of testosterone and $5 \alpha$-reduced androgens by the rabbit prostate and epididymis: studies in vitro and in vivo. J. Endocr. 82, 207-214.

Booth, W.D., Hay, M.F. \& Dott, H.M. (1973) Sexual dimorphism in the submaxillary gland of the pig. $J$. Reprod. Fert. 33, 163-166.

Brown, J.B. (1955) A chemical method for the determination of oestriol, oestrone and oestradiol in human urine. Biochem. J. 60, 185-193.

Burstein, S. \& Lieberman, S. (1958) Hydrolysis of ketosteroid hydrogen sulfates by solvolysis procedures. J. biol. Chem. 233, 331-335.

Callard, G.V., Petro, Z. \& Ryan, K.J. (1978) Phylogenetic distribution of aromatase and other androgen-converting enzymes in the central nervous system. Endocrinology 103, 2283-2290.

Dorfman, R.I. \& Dorfman, A.S. (1963) Assay of androgens administered by inunction to the chicks comb. Acta endocr., Copenh., Suppl. 74, 3-22.

Gower, D.B. (1972) 16-Unsaturated $C_{19}$ steroids, a review of their chemistry, biochemistry and possible physiological role. J. Steroid Biochem. 3, 45-103.

Hemsell, D.L., Edman, C.D., Marks, J.F., Siiteri, P.K. \& MacDonald, P.C. (1977) Massive extraglandular aromatization of plasma androstenedione resulting in feminization of a prepubertal boy. J. clin. Invest. 60 , 455-464.

Joshi, H.S. \& Racside, J.I. (1973) Synergistic effects of testosterone and oestrogens on accessory sex glands and sexual behaviour of the boar. J. Reprod. Fert. 33, $411-423$.

Lindner, H.R. \& Mann, T. (1960) Relationship between the content of androgenic steroids in the testes and the secretory activity of the seminal vesicles. $J$. Endocr. 21, 341-360.

Loriaux, D.L., Ruder, H.J. \& Lipsett, M.B. (1971) The measurement of estrone sulfate in plasma. Steroids 18, 463-472.

Morali, G., Larsson, K., Perez-Palacios, G. \& Beyer, C. (1974) Testosterone, androstenedione, and androstenediol: effects on the initiation of mating behaviour of inexperienced castrated male rats. Horm. Behav. 5, 103-110.
Müntzing, J., Kirdani, R., Murphy, G.P. \& Sandberg, A.A. (1977) Hormonal control of zinc uptake and binding in the rat dorsolateral prostate. Invest. Urol. 14, 492-495.

Naftolin, F., Ryan, K.J., Davies, I.J., Reddy, V.V., Flores, F., Petro, Z., White, R.J., Takaoka, Y. \& Wolin, L. (1975) The formation of oestrogens by central neuroendocrine tissues. Recent Prog. Horm. Res. 31, 295-319.

Newcomb, R., Booth, W.D. \& Rowson, L.E.A. (1977) The effect of oxytocin treatment on the levels of prostaglandin F in the blood of heifers. J. Reprod. Fert. 49, 17-24.

Notation, A.D. (1975) Regulatory interaction for the control of steroid sulfate metabolism. J. Steroid Biochem. 6, 311-316.

Oh, R. \& Tamaoki, B. (1973) In vitro biosynthesis of androgens in canine testes. Acta endocr., Copenh. 74, 615-624.

Raeside, J.I. (1965) Urinary excretion of dehydroepiandrosterone and estrogens by the boar. Acta endocr., Copenh. 50, 611-620.

Raeside, J.I. (1969) The isolation of estrone sulfate and estradiol-17ß sulfate from stallion testes. Can. $J$. Biochem. 47, 811-815.

Raeside, J.I \& Howells, G.A. (1971) The isolation and identification of androstenediol sulfate from the spermatic vein blood and testes of the boar. Can. J. Biochem. 49, 80-84.

Robertson, H.A. \& King, G. J. (1974) Plasma concentration of progesterone, oestrone, oestradiol-17 $\beta$ and of oestrone sulphate in the pig at implantation, during pregnancy and at parturition. J. Reprod. Fert. 40, 133-141.

Ruokonen, A. \& Vihko, R. (1974) Steroid metabolism in testis tissue: concentration of unconjugated and sulfated neutral steroids in boar testis. J. Steroid Biochem. 5, 33-38.

Segal, D.H. \& Raeside, J.I. (1975) Androgens in testes and adrenal glands of the fetal pig. J. Steroid Biochem. 6, 1439-1444.

Signoret, J.P. (1974) Rôle des differentes informations sensorielles dans l'attraction de la femelle en oestrus par le male chez les porcins. Annls Biol. anim. Biochim. Biophys. 14, 747-755.

Singh, M.M. \& Booth, W.D. (1978) Studies on the metabolism of neutral steroids by preimplantation rabbit blastocysts in vitro, and the origin of blastocyst oestrogen. J. Reprod. Fert. 53, 297-304.

Velle, W. (1966) Urinary oestrogens in the male. $J$. Reprod. Fert. 12, 65-73.

Vihko, R. \& Ruokonen, A. (1975) Steroid sulphates in human adult testicular steroid synthesis. $J$. Steroid Biochem. 6, 353-356.

Yamaji, T., Motohashi, K., Tanioka, T. \& Ibayashi, H. (1968) Androstenediol in canine spermatic vein blood and its significance in testosterone biosynthesis in vivo. Endocrinology 83, 992-998.

Received 10 October 1979 